\title{
An Improved Method for Determining \\ Water Holding Capacity of Meat
}

Keisuke КАтоH

Ishikawa Prefecture College of Agriculture, Nonoichi-machi, Ishikawa-ken 921

(Received August 14, 1980)

Centrifuging method and press method are commonly used for determining water holding capacity of meat. Centrifuging method is more accurate of the two. However, for obtaining a measurable amount of centrifugal fluid some measures must be taken such as centrifuging the meat sample for a prolonged length of time ${ }^{1)}$, centrifuging at a high speed ${ }^{2)}$, using a special centrifugal tube ${ }^{3)}$, using a considerable amount $(20 \sim 25$ g each) of meat sample ${ }^{3,4}$, or adding water or salt solution to the meat sample ${ }^{2,4}$. Much effort is necessary especially with fresh meat which gives less juice than heated meat. The author has devised a method for the precise determination of water holding capacity of meat using ordinary experimental equipments.

\section{Materials and Methods}

Meat used was pork Longissimus dorsi, produced at the college farm, stored at $-20^{\circ} \mathrm{C}$ and thawed $24 \mathrm{hr}$ at $4^{\circ} \mathrm{C}$, and unfrozen pork Longissimus dorsi bought from local market.

Tissue paper of about $2 \mathrm{~g}$ was stuffed in the centrifugal tube $(10 \mathrm{ml})$ to the depth of about $2 / 3$ of the tube length. Fresh, minced meat of about $1 \mathrm{~g}$ was placed on the tissue paper and centrifuged. Remaining water in the centrifuged meat was determined by an ordinary method for water analysis, which represents the water holding capacity on the basis of centrifuged meat. Experiments were made to compare various centrifugal conditions.

Since each meat sample was of small amount, it was assumed to be difficult to heat it evenly. Therefore, experiments were also made to compare two different methods of heating: (1) a piece of tissue paper and about $1 \mathrm{~g}$ of minced meat was stuffed in a centrifugal tube in the same manner as above, and dipped in a water bath $70^{\circ} \mathrm{C}$; (2) about $10 \mathrm{~g}$ of minced meat was put in a polyethylene bag and flattened into a $5 \times$ $10 \mathrm{~cm}$ piece and dipped in a water bath, and after a fixed period $1 / 10$ aliquot was crumbled by forceps and taken into a centrifugal tube. These tubes were centrifuged at $671 \times \mathrm{g}$ for $4 \mathrm{~min}$ and the meat samples were analysed for water content.

食肉保水力測定法の改良：加藤啓介（石川県農業短期大学 石川県野々市町 921)

Jpn. J. Zootech. Sci., $52(2): 139-141$ 


\section{Results and Discussion}

The water content was $73.33 \pm 0.37 \%$ (mean \pm s. D. of 10 samples) with the meat used for discussing centrifugal conditions and $73.16 \pm 0.14 \%$ with the meat used for comparing heating methods. Data of water holding capacity are given in Table 1. With non-heated meat samples, water holding capacity was smaller when centrifuged at higher speed, while it was not affected by centrifuging time. Wierbicki et al. ${ }^{\text {s) }}$ also reported that centrifugal force had greater effect than time of centrifugation on the amount of juice separated.

The addition of $20 \%$ water $1^{1 / s}$ hr before centrifugation had no effect on water holding capacity. In other words, the amount of free water does not influence water holding capacity on the basis of centrifuged meat. This also indicates that a slight evaporation from the sample during the analytical process would not cause any error.

Considering the above results, the water holding capacity in the next experiment was determined settling the centrifugal condition at $671 \times \mathrm{g}$ for $4 \mathrm{~min}$.

Variance analysis revealed that the two methods of heating caused significant difference $(P<0.001)$ in water holding capacity. This is partly because the samples heated in the polyethylene bags were crumbled before centrifugation, which enabled free water to be separated more easily.

Water holding capacity was influenced by the length of heating period when the meat was heated in the polyethylene bag, the intermediate length $(6 \mathrm{~min})$ giving the smallest values, but was not significantly influenced when heated in the centrifugal tube. Further investigation in prolonged heating is necessary to explain these irregularities. The samples heated in centrifugal tubes for $1 \mathrm{~min}$ were abandoned because they were partly of raw meat color.

Table 1. Water content of centrifuged meat (\%)

\begin{tabular}{|c|c|c|c|c|}
\hline \multirow{2}{*}{$\begin{array}{l}\text { heating } \\
\text { period }\end{array}$} & \multicolumn{2}{|c|}{ centrifuging } & \multirow{2}{*}{\multicolumn{2}{|c|}{ mean of six samples \pm s. D. }} \\
\hline & force & period & & \\
\hline $\min$ & & $\min$ & (water not added) & $(20 \%$ water added $)$ \\
\hline- & $168 \times g$ & 4 & $69.21 \pm 0.55^{\mathrm{a}}$ & $69.78 \pm 0.46^{\mathrm{a}}$ \\
\hline- & $671 \times \mathrm{g}$ & 4 & $68.30 \pm 0.31^{b}$ & $68.73 \pm 0.11^{b}$ \\
\hline 一 & $671 \times \mathrm{g}$ & 8 & $68.20 \pm 0.23^{b}$ & $68.27 \pm 0.36^{b}$ \\
\hline- & $2680 \times g$ & 4 & $67.26 \pm 0.31^{c}$ & $66.94 \pm 0.63^{c}$ \\
\hline & & & (centrifugal tube $)$ & ( $\left.\begin{array}{c}\text { heated in } \\
\text { polyethylene bag }\end{array}\right)$ \\
\hline 1 & $671 \times \mathrm{g}$ & 4 & $\ldots$ & $65.43 \pm 0.12^{\mathrm{a}}$ \\
\hline 2 & $\|$ & $\|$ & $66.48 \pm 0.20^{\mathrm{a}}$ & $64.99 \pm 0.71^{\mathrm{ab}}$ \\
\hline 4 & $\prime \prime$ & $\prime \prime$ & $66.59 \pm 0.26^{\mathrm{a}}$ & $64.58 \pm 0.22^{b c}$ \\
\hline 6 & $" \prime$ & $\|$ & $66.83 \pm 0.39^{\mathrm{a}}$ & $64.23 \pm 0.32^{b}$ \\
\hline 8 & $\|$ & $\|$ & $66.69 \pm 0.28^{a}$ & $65.19 \pm 0.19^{\mathrm{ac}}$ \\
\hline 10 & $\prime \prime$ & $\|$ & $66.04 \pm 0.28^{a}$ & $65.15 \pm 0.11^{\mathrm{ac}}$ \\
\hline
\end{tabular}

Values with different superscripts are significantly different from other values in the same column at $\mathrm{P}<0.01$. 


\section{Determination of Water Holding Capacity}

In conclusion, present method has following advantages.

(1) It gives precise results (comparable even to whole water analysis), because measurement is not made by volume but by weight.

(2) It requires only a small amount $(1 \mathrm{~g})$ of sample.

(3) It requires nothing else than usual laboratory apparatuses.

(4) Minor extent of wetting or evaporation of samples in the analytical process does not cause error in the results when expressed on the basis of centrifuged meat.

\section{References}

1) Penny, I. F., J. Sci. Food and Agric., 26: 1593-1602. 1975.

2) Grau, R. and R. Hamm, Z. Lebensm.-Untersuch. u. Forsch., 105: 446-460. 1957.

3) Wierbicki, E., L. E. Kunkle and F. E. Deatherage, Food Technol,, 11: 69-73. 1957.

4) Swift, C.E. and R. Ellis, Food Technol., 10: 546-552. 1956. 